\title{
Impact of vitamin D level and supplementation on systemic lupus erythematosus patients during COVID-19 pandemic
}

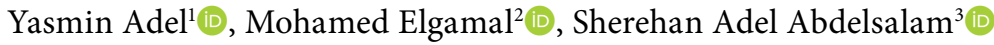 \\ ${ }^{1}$ Department of Physical Medicine and Rehabilitation, Division of Rheumatology, Mansoura University Hospital, \\ Faculty of Medicine, Mansoura, Egypt \\ ${ }^{2}$ Department of Chest, Mansoura University Hospital, Faculty of Medicine, Mansoura, Egypt \\ ${ }^{3}$ Department of Public Health and Community Medicine, Faculty of Medicine, Mansoura, Egypt
}

\begin{abstract}
Objectives: In this study, we aimed to assess the impact of serum vitamin D level in systemic lupus erythematosus (SLE) patients with novel coronavirus-2019 (COVID-19) disease on severity of infection, duration of COVID-19 disease course, and fatigue development as a complication of both SLE and COVID-19.

Patients and methods: Between April 2020 and January 2021, a total of 38 patients (31 males, 7 females; mean age: $49.2 \pm 8.1$ years; range, 38 to 65 years) who were previously diagnosed with SLE and on different lines of lupus management were included. The patients presented to chest outpatient clinic and emergency hospital with manifestations suggesting COVID-19 infection. Vitamin D levels were measured in serum by enzyme-linked immunosorbent assay (ELISA). Vitamin D supplement was added to treatment protocols for COVID-19.

Results: Thirteen (34.2\%) patients had normal baseline serum vitamin $D$ levels ( $\geq 30 \mathrm{ng} / \mathrm{mL}$ ), nine (23.7\%) patients had vitamin $D$ insufficiency (21 to $29 \mathrm{ng} / \mathrm{mL}$ ), and $16(42.1 \%)$ patients had vitamin $D$ deficiency ( $\leq 20 \mathrm{ng} / \mathrm{mL}$ ). Low vitamin D levels (insufficiency \& deficiency) patients had long SLE disease duration $(p=0.06)$. Also, there was a significant long time spent until recovery from COVID-19 infection in low vitamin $D$ levels (insufficiency \& deficiency) patient groups versus those with normal vitamin $D(p=0.019)$. Low baseline vitamin $D$ level patients mainly presented with severe COVID-19 symptoms ( $p=0.04)$. Patients recovered from COVID-19 had normal vitamin $D$ levels than those who died or were lost to follow-up ( $p=0.07$ ). After recovery from COVID-19, fatigue was more common in SLE patients with low baseline vitamin D level.

Conclusion: Vitamin D seems to play a certain role in the management of COVID-19 infection in SLE patients. Patients with normal vitamin D levels have less severe symptoms, shorter time to recovery, improved COVID-19 outcomes, and less development of fatigue after COVID-19 infection.

Keywords: COVID-19, systemic lupus erythematosus, vitamin D.
\end{abstract}

Systemic lupus erythematosus (SLE) is a chronic autoimmune disease characterized by inflammatory reactions all over the body. Clinical presentation ranges from minimal rashes up to fatal complications which include the kidney, heart, and brain. Although the main goal is to reduce inflammation, cases classically demonstrate several manifestations, such as cognitive dysfunctions sleep disorders and easy fatigability. ${ }^{1}$

Hormonal milieu, as well as environmental factor, which include ultraviolet exposure may affect such liability and alteration in disease expression. Development of SLE is believed to

Received: June 11, 2021 Accepted: August 02, 2021 Published online: March 03, 2022

Correspondence: Yasmin Adel, MD. Department of Physical Medicine and Rehabilitation, Division of Rheumatology, Mansoura University Hospital, Faculty of Medicine, 35516 Mansoura, Egypt. Tel: +20502204167 e-mail:yasmin_adel@mans.edu.eg

\section{Citation:}

Adel Y, Elgamal M, Abdelsalam SA. Impact of vitamin D level and supplementation on systemic lupus erythematosus patients during COVID-19 pandemic. Arch Rheumatol 2022;37(2):288-299. 
be due to impairment of key immune regulatory mechanisms implicated in the clearance of nuclear antigens, as well as apoptotic cells. ${ }^{2}$

Discharge of nuclear antigens from cellular damage has the ability to trigger a polyclonal immune response, with a subsequent activation of inflammatory reactions. Such antigens are phagocytosed by plasmacytoid dendritic cells, with a subsequent activation of the type I interferon (IFN) pathways. ${ }^{3}$

T-cells are driven into proinflammatory pathways and regulatory $\mathrm{T}$ cells (Tregs) are usually diminished, inducing hyperactivity of $\mathrm{T}$ helper (Th) cells and producing autoantibodies via the stimulation of autoreactive $\mathrm{B}$ cells. Immune complexes are produced from the aggregation of autoantibodies, as well as self-antigen deposition in many tissues throughout the body, inducing tissue damage with additional discharge of selfantigens. ${ }^{4}$ Proinflammatory cytokines, as well as immune complexes, can improperly stimulate NETosis, where neutrophils release neutrophil extracellular traps (NETs). ${ }^{5}$ The NETs consist of a chromatin backbone attached by particular molecules, as well as free radicals. ${ }^{5}$ Such NETs have the ability to induce tissue damage, as well as augmentation of the immune response. ${ }^{6}$

Additionally, NETs can extend the inflammatory processes through the activation of inflammasome machinery in macrophages, ${ }^{7}$ as well as via the stimulation of dendritic cells to overproduce type I IFN, ${ }^{8}$ encouraging the development and progression of SLE. The term 'vitamin D' was first coined in 1922, describing a vitamin able to promote calcium deposition. ${ }^{9}$ Vitamin D in nature is available as ergocalciferol (vitamin D2) or cholecalciferol (vitamin D3) ${ }^{10}$ and vitamin D2 is mainly present in plants or plant products, while vitamin D3 is normally found in animal source foods. ${ }^{11}$

Vitamin D deficiency (VDD) is usually accompanied by a reduction in Tregs, important for immune tolerance against self-antigens. ${ }^{12}$ In addition, it is known to increase activation of autoreactive $\mathrm{B}$ cells, that may increase autoantibodies generation. ${ }^{13}$ Such form immune complexes with self-antigens activating TLR signaling pathways in plasmacytoid dendritic cells, inducing IFN-alpha (IFN- $\alpha$ ) formation. ${ }^{3}$ In addition, VDD may trigger overstimulation of proinflammatory cytokines production. ${ }^{14}$ Together with immune complexes, such cytokines may ultimately induce tissue damage (by inflammation), with a subsequent additional discharge of self-antigens. ${ }^{4}$

Vitamin D deficiency is thought to be involved in SLE pathogenesis via a number of immunological changes. Several in vitro researches have shown that VDD is associated with immunological aberrations, such as increased IFN- $\alpha$ levels, as well as overstimulation of autoreactive $B$ cells in SLE. ${ }^{13}$ In addition, Vitamin D has been found to suppress the INF-inducible gene overexpression within the dendritic cells. ${ }^{15}$ Therefore, vitamin $\mathrm{D}$ has possible inferences in the preservation of immune tolerance in lupus cases through regulation of dendritic cellular activities.

Novel coronavirus-2019 disease (COVID-19) is a highly contagious disease induced by severe acute respiratory syndrome-coronavirus-2 (SARS-CoV-2), a recently emerged coronavirus which mainly spreads among individuals by close contact and via respiratory droplets when affected subjects cough or sneeze. In addition, infection may develop from touching the infected surfaces followed by face contact. ${ }^{16}$ The SARSCoV-2 is a single positive-stranded ribonucleic acid (RNA) virus $(\sim 30 \mathrm{~kb})$ with a nucleocapsid that undergoes endocytosis or membrane fusion to pass through the affected cells and has the ability to induce respiratory, gastrointestinal tract (GIT), hepatic, and neurologic disorders in various species involving humans.

In terms of the mechanistic point of view, the SARS-CoV-2 has spike (S) glycoproteins composed of two subunits known as S1 protein that attaches to the host cell receptor and the S2 protein that encourage fusion of the viral, as well as cellular membranes. ${ }^{17}$ Angiotensin-converting enzyme 2 (ACE2) is recognized as a functional receptor for SARS-CoV-2 cellular entry, ${ }^{18,19}$ and ACE2 expression is high in the lungs, heart, small intestine, kidneys, and bladder. ${ }^{20}$ The commonest forms of Vitamin D are cholecalciferol and ergocalciferol, which are precursors of activated Vitamin D. ${ }^{21}$ Recently, several researches have been established to measure vitamin $\mathrm{D}$ metabolites in terms of clinical practice to understand the role of Vitamin D in human health. ${ }^{22}$ Vitamin D has many important biological functions which include 
bony metabolism, calcium homeostasis, and recently noticed functions (non-classical) including immunomodulation, lung and muscle functions, as well as contagious disease protection. ${ }^{23}$ In COVID-19 cases, type II pneumocytes are the main target cell of SARS-CoV-2, and their affection reduces the surfactant levels with a higher possibility for acute respiratory distress syndrome (ARDS) development. ${ }^{24}$ Vitamin D is recorded to decrease pneumocytes apoptosis and stimulate surfactant synthesis to avoid marked impairment of respiratory functions. ${ }^{25}$ Sufficient vitamin $\mathrm{D}$ level is broadly described as a serum 25 -hydroxyvitamin D (25(OH)D) level $\geq 30 \mathrm{ng} / \mathrm{mL}$ (75 nmol/L), whereas insufficient vitamin $\mathrm{D}$ level is described as 20 to $30 \mathrm{ng} / \mathrm{mL}$ ( 50 to $75 \mathrm{nmol} / \mathrm{L}$ ) and VDD is a level below $20 \mathrm{ng} / \mathrm{mL}$ (50 nmol/L). ${ }^{26}$ A low level is frequently seen in the elderly and cases with comorbidities such as septicemia, and that vitamin $\mathrm{D}$ therapy may markedly decrease the mortality rate. ${ }^{27}$

In the present study, the primary objective was to assess the impact of serum vitamin $\mathrm{D}$ level in SLE patients with COVID-19 disease on severity of infection and pandemic treatment outcome. The secondary objectives were to investigate the effect of serum vitamin D level in SLE patients on duration of COVID-19 disease course and fatigue development as a complication for both SLE and COVID-19 and to analyze the correlation of serum vitamin $\mathrm{D}$ level with different laboratory investigations at time of COVID-19 outbreak.

\section{PATIENTS AND METHODS}

This observational study was conducted at Mansoura University Hospital, Faculty of Medicine, Department of Physical Medicine and Rehabilitation, Division of Rheumatology, between April 2020 and January 2021. A total of 38 patients (31 males, 7 females; mean age: $49.2 \pm 8.1$ years; range, 38 to 65 years) with a history of SLE presented to chest diseases outpatient clinic with symptoms suggestive of COVID-19 infection (e.g., fever, bone aches, fatigue, cough, variable degree of dyspnea and/or diarrhea) were included. The diagnosis of SLE was confirmed by the patients and/or their relatives and using the archived laboratory and radiological reports. All patients were on different lines of
SLE treatment (disease-modifying antirheumatic drugs [DMARDs]+immunosuppressive drugs) and some patients were adherent to vitamin D supplementation (alphacalcidol). All patients were subjected to thoracic computed tomography (CT), laboratory tests (complete blood count, erythrocyte sedimentation rate [ESR], C-reactive protein [CRP], serum ferritin, D-dimer \pm polymerase chain reaction [PCR] for COVID-19, whenever possible). Diagnosis of COVID-19 infection was confirmed by either positive PCR for viral infection (through throat or nasal swabs) or chest staff panel decision based of characteristic patchy ground glass lung infiltration with any of high ESR, CRP, ferritin, and D-dimer or absolute lymphopenia. Serum vitamin D level was assessed from blood samples for all patients by enzyme-linked immunosorbent assay (ELISA). Vitamin D was considered deficient if $\leq 20 \mathrm{ng} / \mathrm{mL}$, insufficient if 21 to $29 \mathrm{ng} / \mathrm{mL}$, and normal if $\geq 30 \mathrm{ng} / \mathrm{mL} .{ }^{28}$ All patients started institutional protocol for COVID-19 management (ceftriaxone, azithromycin, anticoagulant, antiviral, multivitamins and steroids). All patients received vitamin D added to anti-COVID treatment (vitamin D2- ergocalciferol or vitamin D3- cholecalciferol). Some patients were admitted to intensive care unit (ICU) in case of severe chest symptoms. Baseline vitamin $\mathrm{D}$ serum level at the time of COVID-19 diagnosis was correlated with different clinical, severity of COVID symptoms, laboratory investigations, and COVID-19 outcomes after treatment course. Recovered patients were subjected to measurement of serum vitamin D eight weeks after recovery to asses the impact of vitamin D supplementation on correction of baseline serum level. Fatigue was evaluated four weeks after recovery from COVID-19 infection by Fatigue Severity Scale (FSS) ${ }^{29}$ to demonstrate the efficacy of normal vitamin $\mathrm{D}$ level on fatigue as a complication for both SLE and COVID-19.

\section{Statistical analysis}

Statistical analysis was performed using the SPSS version 16.0 software (SPSS Inc., Chicago, IL, USA). Descriptive data were expressed in mean \pm standard deviation (SD), median (min-max) or number and frequency, where applicable. The relations between qualitative variables were evaluated using the chi-square test or Fisher exact test, as appropriate. The relations between continuous variables were evaluated using the Pearson correlation test. Significant 
differences between the means of the variables were evaluated using the Mann-Whitney $\mathrm{U}$ test. A two-sided $p$ value of $<0.05$ was considered statistically significant.

\section{RESULTS}

Of a total of 38 SLE patients included in the study, 13 (34.2\%) had normal baseline serum vitamin D levels ( $\geq 30 \mathrm{ng} / \mathrm{mL}$ ), nine $(23.7 \%)$ had vitamin D insufficiency (21 to $29 \mathrm{ng} / \mathrm{mL}$ ), and 16 patients (42.1\%) had Vit D deficiency $(\leq 20 \mathrm{ng} / \mathrm{mL})$. In total cohort, basal vitamin $\mathrm{D}$ level (mean $\pm \mathrm{SD} ; 23.4 \pm 8.3 \mathrm{ng} / \mathrm{mL}$ ) was negatively associated with age $(p=0.9)$, ESR $(p \leq 0.05)$, CRP $(p=0.1)$, ferritin level $(p=0.59)$ and $\mathrm{D}$ dimer $(\mathrm{p}=0.9)$ while it was positively correlated with absolute lymphocyte count at time of COVID-19 diagnosis $(p \leq 0.05)$. The patients with low vitamin D levels (insufficiency \& deficiency) had significantly higher 1-h ESR levels $(52.6 \pm 18.7$ vs. $35.9 \pm 8.9 \mathrm{~mm} / \mathrm{h}$, respectively; $\mathrm{p}<0.05)$ and lymphopenia $(1080 \pm 789.5$ vs. $1930.8 \pm 1047.5 / \mathrm{cmm}$, respectively; $\mathrm{p}<0.05)$. Low vitamin $\mathrm{D}$ level (insufficiency \& deficiency) patients at the time of COVID-19 infection found to have a marginal significant longer SLE disease duration than patients with normal vitamin $D$ levels $(6.2 \pm 3.7$ vs. $3.9 \pm 3.3$ years, respectively; $\mathrm{p}<0.05$ ). Also, there was a significant long time spent till recovery from COVID-19 infection in low vitamin $D$ level (insufficiency \& deficiency) patients than patients with normal vitamin $D$ levels $(22.7 \pm 4.8$ vs. $18.5 \pm 3.6$ days, respectively; $\mathrm{p}<0.05$ ) (Tables 2 and 3).

The patients with low $(<30 \mathrm{ng} / \mathrm{mL})$ baseline vitamin D level (vitamin D insufficiency and deficiency) significantly presented with more severe COVID-19 symptoms (68\%) than patients with normal vitamin D levels $(30.8 \%)(p<0.05)$. Also, the patients who presented with severe COVID-19 infection had low baseline vitamin $\mathrm{D}$ levels than those having mild-to-moderate symptoms $(19.5 \pm 9.1$ vs. $20.0 \pm 6.2 \mathrm{ng} / \mathrm{mL}$, respectively; $p<0.05)$. There was no significant difference in baseline vitamin $\mathrm{D}$ levels between the patients that were adherent to vitamin D supplementation and non-adherent group $(p=0.1)$ (Figure 1, Tables 4 and 5).

Thirty-one $(81.5 \%)$ patients recovered from COVID-19 infection ( $n=20,64.5 \%$ with low baseline vitamin $\mathrm{D}$ levels), while seven (18.5\%) patients died or lost to follow-up $(\mathrm{n}=5,71.4 \%$ with low baseline vitamin D levels). Baseline vitamin D level was marginally significantly lower in non-survivors or lostto-follow-up patients $(17.2 \pm 6.6 \mathrm{ng} / \mathrm{mL})$ than survivors $(23.6 \pm 8.5 \mathrm{ng} / \mathrm{mL})(p<0.05)$. However, chloroquine treatment within the past six months prior to infection did not affect COVID-19 treatment outcome and no

\begin{tabular}{|c|c|c|c|}
\hline & $\mathrm{n}$ & $\%$ & Mean \pm SD \\
\hline Age (year) & & & $49 \pm 8.3$ \\
\hline $\begin{array}{l}\text { Sex } \\
\quad \text { Male } \\
\quad \text { Female }\end{array}$ & $\begin{array}{c}7 \\
31\end{array}$ & & \\
\hline Vitamin D & & & $23.4 \pm 8.3$ \\
\hline Erythrocyte sedimentation rate & & & $46.9 \pm 17.8$ \\
\hline C-reactive protein & & & $40 \pm 27.5$ \\
\hline Ferritin & & & $330.5 \pm 165$ \\
\hline D-dimer (ng/mL) & & & $193.6 \pm 125.1$ \\
\hline Lymphocyte & & & $1371 \pm 963$ \\
\hline Normal Vitamin D ( $\geq 30 \mathrm{ng} / \mathrm{mL})$ & 13 & 34.2 & \\
\hline Vitamin D insufficiency $(21-29 \mathrm{ng} / \mathrm{mL})$ & 9 & 23.7 & \\
\hline Vitamin D deficiency $(\leq 20 \mathrm{ng} / \mathrm{mL})$ & 16 & 42.1 & \\
\hline
\end{tabular}


Table 2. Correlation of baseline vitamin D levels with laboratory parameters

\begin{tabular}{|c|c|c|c|c|c|c|}
\hline & Age (years) & $\operatorname{ESR}(\mathrm{mm} / \mathrm{h})$ & $\mathrm{CRP}(\mathrm{mg} / \mathrm{L})$ & Ferritin $(\mathrm{ng} / \mathrm{mL})$ & Lymphocyte (/cmm) & $\mathrm{D}$ dimer $(\mathrm{ng} / \mathrm{mL})$ \\
\hline & Mean \pm SD & Mean \pm SD & Mean \pm SD & Mean \pm SD & Mean \pm SD & Mean \pm SD \\
\hline Vit D (ng/mL) & $49 \pm 8.3$ & $46.9 \pm 17.8$ & $40 \pm 27.5$ & $330.5 \pm 165$ & $1371 \pm 963$ & $193.6 \pm 125.1$ \\
\hline r & -0.018 & -0.46 & -0.25 & -0.08 & 0.4 & -0.01 \\
\hline$p$ & 0.9 & $\leq 0.05$ & 0.1 & 0.59 & $\leq 0.05$ & 0.9 \\
\hline
\end{tabular}

ESR: Erythrocyte sedimentation rate; CRP: C-reactive protein; SD: Standard deviation; Vit. D: Vitamin D.

Table 3. Laboratory data, SLE disease duration, and time to COVID recovery between normal and low vitamin D level patient groups

\begin{tabular}{|c|c|c|c|}
\hline & $\begin{array}{c}\text { Low Vit D } \\
\text { (insufficiency \& deficiency) } \\
(\leq 29 \mathrm{ng} / \mathrm{mL})(\mathrm{n}=25)\end{array}$ & $\begin{array}{l}\text { Normal Vit D } \\
(\geq 30 \mathrm{ng} / \mathrm{mL}) \\
(\mathrm{n}=13)\end{array}$ & \\
\hline & Mean \pm SD & Mean \pm SD & $p$ \\
\hline Age (year) & $49.2 \pm 8$ & $48.5 \pm 9.1$ & 0.4 \\
\hline $1^{\text {st }}$ hour ESR $(\mathrm{mm} / \mathrm{h})$ & $52.6 \pm 18.7$ & $35.9 \pm 8.8$ & $\leq 0.05$ \\
\hline $\mathrm{CRP}(\mathrm{mg} / \mathrm{L})$ & $39.7 \pm 28.1$ & $40.6 \pm 27.4$ & 0.7 \\
\hline Ferritin (ng/mL) & $338.4 \pm 167.8$ & $315.5 \pm 164.9$ & 0.6 \\
\hline Lymphocyte (/cmm) & $1080 \pm 789.5$ & $1930.7 \pm 1047.5$ & $\leq 0.05$ \\
\hline D dimer $(\mathrm{ng} / \mathrm{mL})$ & $208.3 \pm 120.2$ & $165.3 \pm 134.4$ & 0.2 \\
\hline SLE disease duration (year) & $6.1 \pm 3.7$ & $3.8 \pm 3.2$ & 0.061 \\
\hline Duration till COVID-19 recovery (day) & $22.6 \pm 4.7$ & $18.5 \pm 3.6$ & $\leq 0.05$ \\
\hline
\end{tabular}

significant difference in the recovery rate was observed between the patients receiving chloroquine six months prior to COVID-19 infection and those not receiving $(p=0.16)$ (Table 6).
The patients that recovered from COVID-19 $(n=31)$ were subjected to serum vitamin $D$ level measurement after eight weeks from recovery. Eleven patients who had normal levels at the time of infection remained having normal

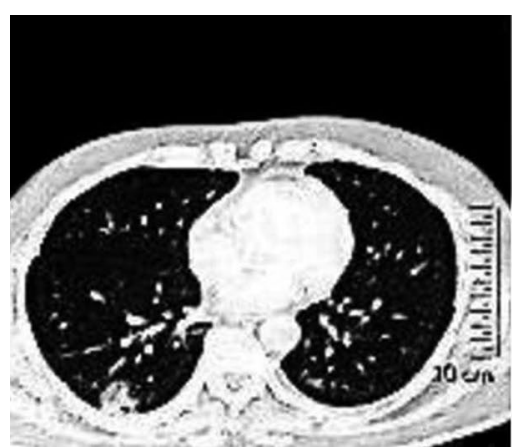

Mild infection

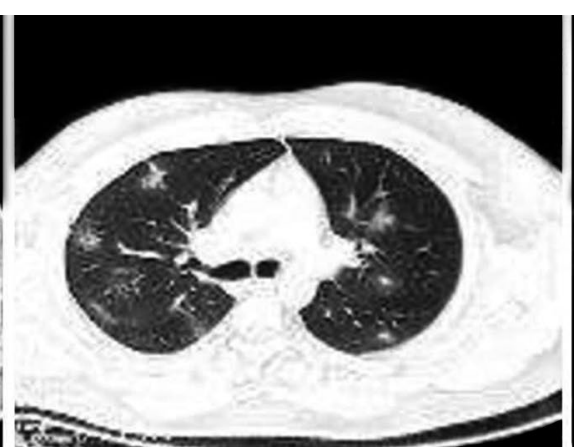

Moderete infection

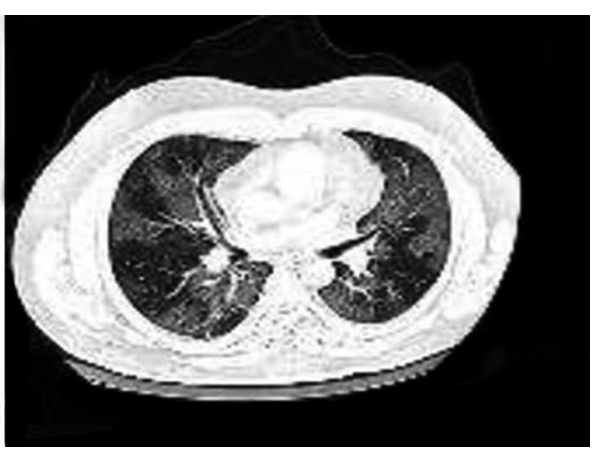

Sever infection

Figure 1. Thoracic computed tomography showing mild, moderate, and severe COVID-19 infection.

COVID-19: Novel coronavirus-2019. 


\begin{tabular}{|lccc|}
\hline \multicolumn{4}{|c|}{ Table 4. Vitamin D level with COVID-19 severity and impact of previous supplement } \\
\hline Mild \& moderate symptoms & $\mathrm{n}$ & Mean \pm SD & $p$ \\
Sever symptoms & 17 & $20 \pm 6.2$ & $\leq 0.05$ \\
Was not adherent to Vit D supplement & 21 & $19.5 \pm 9$ & \\
Was adherent to Vit D supplement & 29 & $23.3 \pm 8.2$ & \\
\hline COVID-19: Novel coronavirus-2019; SD: Standard deviation. & 9 & $19.5 \pm 9.2$ & \\
\end{tabular}

Table 5. Severity of COVID-19 between patient groups

\begin{tabular}{|c|c|c|c|c|c|c|}
\hline & \multicolumn{2}{|c|}{ Sever COVID symptoms } & \multicolumn{2}{|c|}{ Mild and moderate COVID symptoms } & \multirow[b]{2}{*}{$\chi^{2}$} & \multirow[b]{2}{*}{$p$} \\
\hline & $\mathrm{n}$ & $\%$ & $\mathrm{n}$ & $\%$ & & \\
\hline Low Vit D (insufficiency and deficiency) & 17 & 68.0 & 8 & 32 & \multirow{2}{*}{4.7} & \multirow{2}{*}{$\leq 0.05$} \\
\hline Normal Vit D & 4 & 30.8 & 9 & 69.2 & & \\
\hline
\end{tabular}

Table 6. Vitamin D levels according to SLE treatment and impact on recovery from COVID-19

\begin{tabular}{|c|c|c|c|}
\hline & $\mathrm{n}$ & Mean \pm SD & $p$ \\
\hline On MTX \pm chloroquine \pm steroid \pm immunosuppressive & 21 & $20.5 \pm 8.8$ & \multirow{2}{*}{0.11} \\
\hline On MTX \pm steroid \pm immunosuppressive & 17 & $24.8 \pm 7.6$ & \\
\hline Recovered & 31 & $23.6 \pm 8.5$ & \multirow{2}{*}{0.06} \\
\hline Died or lost to follow-up & 7 & $17.2 \pm 6.6$ & \\
\hline
\end{tabular}

vitamin D levels eight weeks after recovery, while in 16 of 20 patients who had low baseline vitamin $\mathrm{D}$ levels, the levels returned to normal range eight weeks after recovery. Fatigue was

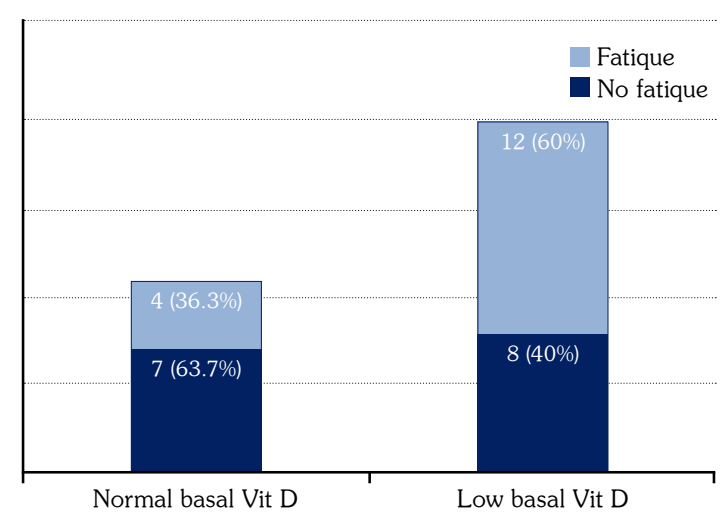

Figure 2. Vitamin D level and its impact on fatigue. Vit. D: Vitamin D. one of commonest manifestation of both SLE and post-COVID-19. Fatigue was evaluated in 31 patients that recovered from infection; four of $11(36.3 \%)$ patients with normal baseline vitamin D levels and 12 of 20 (60\%) patients with low baseline vitamin $\mathrm{D}$ levels had persistent fatigue (Figure 2).

\section{DISCUSSION}

In human body, vitamin $\mathrm{D}$ is derived mainly from cutaneous biosynthesis and partfly from diet. To be active in terms of the biological level, vitamin $\mathrm{D}$ undergoes sequential enzymatic reactions via hydroxylation initially to $25(\mathrm{OH}) \mathrm{D}$, and then primarily in the renal tissue, the enzyme $1 \alpha$-hydroxylase

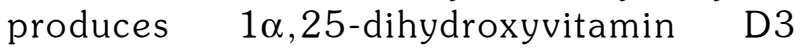
(activated Vitamin D). Regarding systemic 
point of view, vitamin $\mathrm{D}$ has an essential function in calcium homeostasis, as well as bone metabolism, through binding the vitamin $\mathrm{D}$ receptor (VDR) to control expression of the downstream genes of vitamin D. ${ }^{23}$

There are two types of immunity: innate and adaptive immunity. The innate immunity is the first defense line depending mainly on the lining mucosa, monocyte, neutrophil and macrophage, which acts as antigen-presenting cells activating B and T lymphocytes. The expression of CYP27B1 and VDR can be detected in the majority of immune cells such as macrophages, dendritic cells, and activated lymphocytes. ${ }^{30}$ Emerging data focus on the stimulation of natural killer (NK) cells as contributor to both resolution of SARS-CoV-2 infection, and the cytokine storms present in ARDS. ${ }^{31}$ Several researches have shown impairment in cellular functions of $e x$ vivo NK cells detected in COVID-19 cases. $^{31}$ Also, prior researches have recommended that the reduction in serum calcitriol may share in the reduction of $\mathrm{NK}$ activity in cases with chronic diseases, and vitamin D therapy may dramatically increase cytotoxicity and exocytosis of NK cells. ${ }^{32}$

Vitamin D has been demonstrated to have antibacterial and antiviral properties via cathelicidin (LL37), which encourages the induction of free radicals and the suppression of biosynthesis of phospholipids. ${ }^{33}$ In addition, vitamin D triggers macrophage differentiation, as well as up regulation of CD14 expression and the TLRs 2/4 co-receptor, triggering CYP27B1 expression in macrophages and suppressing dendritic cells maturation and block their antigen presentation which initiates an adaptive response. Vitamin $\mathrm{D}$ has a main function in the enhancement of Treg cell development and balancing Th cellular responses to guard against microbes and reduce proinflammatory cytokines discharge. ${ }^{34}$

Low levels of vitamin $\mathrm{D}$ have been reported to be involved in the pathogenesis of many infectious diseases such as bacterial or viral infections of the respiratory tract which include tuberculosis and influenza, human immunodeficiency virus (HIV), Epstein-Barr virus (EBV), hepatitis $\mathrm{C}$ virus (HCV), parasitic infections of the GIT, and systemic fungal infection. ${ }^{34}$
Furthermore, vitamin $\mathrm{D}$ is a component of innate responses needed to keep respiratory tract health. Mechanistically, acute viral respiratory tract infections are found to upregulate CYP27B1 in respiratory epithelial cells, converting local stores of vitamin D into 1,25-dihydroxyvitamin $\mathrm{D}$ leading to the induction of LL37. ${ }^{35}$ This increase in activated vitamin $\mathrm{D}$ after that induces downstream alterations in gene expression, eventually decreasing inflammation while keeping antiviral functions. ${ }^{36}$ Vitamin $\mathrm{D}$ therapy has been demonstrated to be associated with a marked elevation of LL37 levels, that recruits neutrophils, monocytes, and $\mathrm{T}$ cells to affected tissues, inhibits the activity of microbes, and encourages clearance of respiratory microbes by induction of apoptosis in the affected epithelial cells. ${ }^{37}$ At the initial phase of acute inflammation, vitamin D suppresses Th1 and Th17 cellular proliferation and the abnormal discharge of their cytokines, ${ }^{38}$ while, in the resolution phase, vitamin D-mediated differentiation of Th2 cells and discharge of their cytokines are essential to prevent tissue injury through a marked immune response. In terms of the mechanistic level, vitamin $\mathrm{D}$ therapy has the ability to reduce messenger RNA (mRNA) expression of IFN-beta (IFN- $\beta$ ) and IFN-stimulated genes. ${ }^{39}$ Taking into consideration its function as a potent immunosuppressor, it may suppress the abnormalities in immune response, as well as cytokine storm of COVID-19.

In our study, we reported that vitamin $\mathrm{D}$ levels were lower in older age patients than younger age, consistent with a previous study conducted in Norway which showed that activated vitamin $\mathrm{D}$ reduced from $140 \mathrm{pmoL} / \mathrm{L}$ in patients aged between 20 and 39 years and to $98 \mathrm{pmoL} / \mathrm{L}$ in patients aged older than 80 years. ${ }^{23}$ Serum $25(\mathrm{OH}) \mathrm{D}$ concentrations tend to decrease with age, which may be important for COVID-19 as case-fatality rates (CFRs) increase with age.$^{40}$ The main reasons include less time spent in the sun and reduced production of vitamin $\mathrm{D}$ as a result of lower levels of 7-dehydrocholesterol in the skin. ${ }^{41}$ In addition, some pharmaceutical drugs decrease serum $25(\mathrm{OH}) \mathrm{D}$ levels by activating the pregnane $\mathrm{X}$-receptor. ${ }^{42}$ Such drugs include antiepileptics, antineoplastics, antibiotics, anti-inflammatory agents, antihypertensives, 
antiretrovirals, endocrine drugs, and particular herbal medicines. Pharmaceutical drug use usually increases with age.

A recent study has shown that serum levels of activated vitamin D are markedly reduced in non-survivors compared to survivors between cases with sepsis. ${ }^{27}$ This is consistent with data we observed in our study that SLE patients presenting with more severe COVID-19 chest symptoms had lower levels of vitamin $\mathrm{D}$. The critical role of vitamin $\mathrm{D}$ can be also observed in certain malignancies, and vitamin $\mathrm{D}$ requires CYP27B1 to create active vitamin D. In a study of type of bone marrow (BM) malignancy cells, the authors noticed considerably minimal levels of CYP27B1 proteins within BM cells compared to non-AML individuals. ${ }^{43}$

Current guidelines have suggested a target level of 30 to $40 \mathrm{ng} / \mathrm{mL}$ for cases with a possibility of fractures, falling, autoimmune disorders, and malignant tumors. The recommended dose of vitamin $\mathrm{D}$ therapy is $<10,000 \mathrm{IU}$ per day with a target 25-hydroxyvitamin D level of $30 \mathrm{ng} / \mathrm{mL}$ or more for affected cases. ${ }^{44}$ A dose below $4000 \mathrm{IU} /$ day is considered to be safe. ${ }^{45}$ The commonest formulae of vitamin $\mathrm{D}$ therapies are cholecalciferol and ergocalciferol, although the administration of calcitriol is restricted due to the possible development of hypercalcemiaassociated adverse effects. Accordingly, we considered a vitamin D level less than $30 \mathrm{ng} / \mathrm{mL}$ to be low in SLE patients.

In a previous study of vitamin $\mathrm{D}$ therapy for SLE affected cases, high dosages of vitamin D could decrease disease progression. ${ }^{46}$ It is of great importance to consider that, although vitamin D3 and ergocalciferol have a higher safety profile compared to activated vitamin $\mathrm{D}$, full dosages of vitamin $\mathrm{D}$ therapy may induce also hypercalcemia, which is considered an additional main drawback of vitamin D therapy. In our study, we found that SLE patients who had low baseline vitamin $\mathrm{D}$ levels had a more aggressive COVID-19 course with a prolonged duration until recovery from infection. Also, the SLE patients with low vitamin D levels were less likely candidate to overcome COVID-19 infection than those having normal vitamin $\mathrm{D}$ levels. This could be explained by the fact that COVID-19 patients with severity of the illness is frequently determined by the presence of pneumonia/ ARDS, myocarditis, microvascular thrombosis and/or cytokine storm, all of which involve underlying inflammation. While the COVID-19specific CD8 T cells and the specific antibodies produced by $\mathrm{B}$ cells are critical for eliminating the virus, uncontrolled non-specific inflammation, and cytokine release can cause catastrophic injury to the lungs and other vital organs. Consequently, decreasing this early non-specific inflammation during COVID-19 may provide time for the development of specific acquired immunity against COVID-19.

A principal defense against uncontrolled inflammation and against viral infection, in general, is provided by Tregs. These cells are displayed to be lower in one group of COVID-19 cases and markedly lower in severe cases. ${ }^{47}$ In a study of older nursing home patients, high Treg blood levels were found to be associated with a reduced level of respiratory viral disease. ${ }^{48}$ These findings suggest that, if Treg levels can be increased, this may be of benefit in diminishing the severity of viral disease and, probably, of COVID-19.

Moreover, Treg levels can be increased by vitamin $\mathrm{D}$ therapy. ${ }^{49}$ The significance of vitamin $\mathrm{D}$ in cases of respiratory infection is illustrated by the fact that low vitamin $\mathrm{D}$ levels are common worldwide and low levels have been associated with a higher possibility of pneumonia development. ${ }^{50}$ and viral upper respiratory tract infections. ${ }^{51}$ Vitamin D deficiency $(25(\mathrm{OH}) \mathrm{D}$ $<50 \mathrm{nmol} / \mathrm{L}$ ) is present in 30 to $60 \%$ of the populations of Western, Southern, and Eastern Europe and, in up to $80 \%$ of populations in Middle Eastern countries. ${ }^{52}$ In addition, even more severe deficiency (serum levels $<30 \mathrm{nmol} / \mathrm{L}$ ) is reported in over $10 \%$ of Europeans.

A study of healthy women in the United States found a significant inverse relationship between the serum levels of $25(\mathrm{OH}) \mathrm{D}$ and tumor necrosis factor-alpha $(\mathrm{TNF}-\alpha){ }^{53}$ In another report, the levels of interleukin (IL)-6 were found to be increased in vitamin $\mathrm{D}$ deficient individuals. ${ }^{54}$ These studies raise the possibility that adequate levels of vitamin $\mathrm{D}$ may reduce the incidence of cytokine storm, which can occur in COVID-19. It is also observed that Vitamin D supplementation 
enhances the expression of genes related to antioxidation (glutathione reductase and glutamate-cysteine ligase modifier subunit). ${ }^{54}$ The increased glutathione production spares the use of ascorbic acid (vitamin C), which has antimicrobial activities, ${ }^{55}$ and is suggested to prevent and treat COVID-19. ${ }^{56}$

Thrombotic complications are common in COVID-19 patients. Of those with severe disease, more than $50 \%$ have been found to have elevated $\mathrm{D}$-dimer levels. Interestingly, vitamin $\mathrm{D}$ is also involved in the regulation of thrombotic pathways, and VDD is associated with an increase in thrombotic episodes. ${ }^{57}$ This finding was also observed in our study in that SLE patients with low vitamin D levels presented with higher levels of $\mathrm{D}$-dimer that is usually associated with more aggressive disease.

Vitamin $D$ deficiency may cause fatigue via upregulation of nuclear factor kappa-B (NF-кB). It is accompanied by a higher NF- $\mathrm{BB}$ expression, which upon stimulation activates the production of numerous sleep-promoting substances including IL- $1 \beta$ and TNF- $\alpha .{ }^{58}$ Such transcription factor is stimulated within the hypothalamus. ${ }^{59}$ Vitamin D comprises an essential protective function in the central nervous system (CNS) by prevention of oxidative damage, as well as inhibition of production of proinflammatory cytokines such as TNF- $\alpha$, IL- 6 and nitric oxide in cultured microglial cells, ${ }^{60}$ that is increased in SLE. In addition, autoantibodies binding to double-stranded deoxyribonucleic acid (ds-DNA) have the ability to cross react with the Anti-N-methyl-D-aspartate receptor (NMDAR) present in neuronal cells of SLE cases, playing an essential function in memory regulation. ${ }^{61}$ Anti-NMDAR antibodies can elicit neuronal cell death in mice and, accordingly, induce cognitive impairments, as well as emotional alterations. ${ }^{62}$ Recently, it has been discovered that, compared to normal individuals, lower vitamin D levels are observed in cases with anti-NDMAR encephalitis, an autoimmune state which usually presents with fatigue and several neuropsychiatric manifestations. ${ }^{63}$

In the current study, we observed that most of SLE patients with low vitamin D levels even after vitamin D supplementation complained from fatigue than patients with normal vitamin $\mathrm{D}$ levels at the time of study inclusion. Thus, there are possible implications that VDD can induce fatigue via neurological damage mediated by anti-NDMAR antibodies in lupus cases. Fatigue in lupus cases is multifactorial, with depression and mood changes displaying a marked effect in the majority of patients. ${ }^{64}$ Many theories have suggested that a complex interplay is present among vitamin D condition, cognition, and mood in lupus cases. In a pivotal study, neuropsychiatric tests were carried out in 61 lupus cases to evaluate cognition, and blood specimens were withdrawn from entire cases to measure 25(OH)D3 levels. ${ }^{65}$ Compared to normal individuals, significantly higher levels of cognitive impairment as well as a greater incidence of VDD were detected in lupus cases. Remarkably, 25(OH)D3 deficiency $(<10 \mathrm{ng} / \mathrm{mL})$ independently predicted cognitive impairment in lupus cases following adjustment of many potential confounders such as age, education status, sex, and accumulated corticosteroid dosage $(p<0.025)$. In addition, comparable findings were noticed in another study which demonstrated that 25(OH)D3 levels had an inverse correlation with neuropsychiatric Systemic Lupus Erythematosus Disease Activity Index (SLEDAI) scores $(p=0.03) .{ }^{66}$

Another study demonstrated that vitamin $\mathrm{D}$ therapy markedly decreased the disease progression and fatigue levels in a cohort of pediatric SLE cases over a duration of six months. ${ }^{67}$ Moreover, serum 25(OH)D levels were measured at baseline $(19.1 \pm 60 \mathrm{ng} / \mathrm{mL}$ for the cases and $19.5 \pm 40 \mathrm{ng} / \mathrm{mL}$ for the controls) and after six months of therapy with oral vitamin D3. The final results demonstrated that pediatric SLE cases on vitamin D had markedly greater levels of $25(\mathrm{OH}) \mathrm{D}$ than the controls $(31.3 \pm 8.7$ vs. $16.5 \pm 5.8$, respectively; $p<0.05)$, with $70 \%$ of those managed reaching satisfactory levels of $25(\mathrm{OH}) \mathrm{D} .{ }^{67}$

Additionally, a study was carried out by RuizIrastorza et al. ${ }^{68}$ in 80 lupus cases over a period of 24 months. In this study, 60 cases were given vitamin D3 by oral ingestion with an average dose of $800 \mathrm{IU} /$ day. At the T2 time point, a marked improvement in lupus-associated fatigue was noticed compared to baseline.

We recommend to conduct future studies to evaluate impact of vitamin $\mathrm{D}$ level on different variant of COVID-19. 
In conclusion, COVID-19 is still an outbreak without a standard treatment algorithm. It is reported that vitamin $\mathrm{D}$ is needed for normal immune functions to fight microbes and prevent autoimmune disorders. Vitamin D is a low-cost drug that improves fatigue and quality of life for SLE patients. Normal levels of vitamin D during COVID-19 infection decrease severity of symptoms, shorten time to recovery, and enhance improvement of COVID-19 outcomes in SLE patients. Vitamin D supplementation is associated with less development of fatigue after COVID-19 infection in SLE patients.

Ethics Committee Approval: The study protocol was approved by the Institutional research board of faculty of medicine, Mansoura University, Egypt (IRB No. Rb. 21.01.91). The study was conducted in accordance with the principles of the Declaration of Helsinki.

Patient Consent for Publication: A written informed consent was obtained from each patient.

Data Sharing Statement: The data that support the findings of this study are available from the corresponding author upon reasonable request.

\section{Author Contributions: ___Y.A., _-_M.E., S.A.A.}

Conflict of Interest: The authors declared no conflicts of interest with respect to the authorship and/or publication of this article.

Funding: The authors received no financial support for the research and/or authorship of this article.

\section{REFERENCES}

1. Jump RL, Robinson ME, Armstrong AE, Barnes EV, Kilbourn KM, Richards HB. Fatigue in systemic lupus erythematosus: Contributions of disease activity, pain, depression, and perceived social support. J Rheumatol 2005;32:1699-705.

2. Mok CC, Lau CS. Pathogenesis of systemic lupus erythematosus. J Clin Pathol 2003;56:481-90.

3. Lövgren T, Eloranta ML, Båve U, Alm GV, Rönnblom $\mathrm{L}$. Induction of interferon-alpha production in plasmacytoid dendritic cells by immune complexes containing nucleic acid released by necrotic or late apoptotic cells and lupus IgG. Arthritis Rheum 2004;50:1861-72.

4. Liu Z, Davidson A. Taming lupus-a new understanding of pathogenesis is leading to clinical advances. Nat Med 2012;18:871-82.
5. Yu Y, Su K. Neutrophil extracellular traps and systemic lupus erythematosus. J Clin Cell Immunol 2013;4:139.

6. Kessenbrock K, Krumbholz M, Schönermarck U, Back W, Gross WL, Werb Z, et al. Netting neutrophils in autoimmune small-vessel vasculitis. Nat Med 2009; 15:623-5.

7. Kahlenberg JM, Carmona-Rivera C, Smith CK, Kaplan MJ. Neutrophil extracellular trap-associated protein activation of the NLRP3 inflammasome is enhanced in lupus macrophages. J Immunol 2013;190:1217-26.

8. Lande R, Ganguly D, Facchinetti V, Frasca L, Conrad C, Gregorio J, et al. Neutrophils activate plasmacytoid dendritic cells by releasing self-DNApeptide complexes in systemic lupus erythematosus. Sci Transl Med 2011;3:73ra19.

9. O'Riordan JL, Bijvoet OL. Rickets before the discovery of vitamin D. Bonekey Rep 2014;3:478.

10. Wacker M, Holick MF. Vitamin D - effects on skeletal and extraskeletal health and the need for supplementation. Nutrients 2013;5:111-48.

11. Barvencik F, Amling M. Vitamin D metabolism of the bone. Orthopade 2015;44:686-94. German.

12. Terrier B, Derian N, Schoindre Y, Chaara W, Geri $\mathrm{G}$, Zahr $\mathrm{N}$, et al. Restoration of regulatory and effector $\mathrm{T}$ cell balance and $\mathrm{B}$ cell homeostasis in systemic lupus erythematosus patients through vitamin D supplementation. Arthritis Res Ther 2012;14:R221.

13. Singh A, Kamen DL. Potential benefits of vitamin D for patients with systemic lupus erythematosus. Dermatoendocrinol 2012;4:146-51.

14. Shahin D, El-Farahaty RM, Houssen ME, Machaly SA, Sallam M, ElSaid TO, et al. Serum 25-OH vitamin D level in treatment-naïve systemic lupus erythematosus patients: Relation to disease activity, IL-23 and IL-17. Lupus 2017;26:917-26.

15. Ben-Zvi I, Aranow C, Mackay M, Stanevsky A, Kamen $\mathrm{DL}$, Marinescu LM, et al. The impact of vitamin D on dendritic cell function in patients with systemic lupus erythematosus. PLoS One 2010;5:e9193.

16. Xu Y, Baylink DJ, Chen CS, Reeves ME, Xiao J, Lacy $\mathrm{C}$, et al. The importance of vitamin $\mathrm{d}$ metabolism as a potential prophylactic, immunoregulatory and neuroprotective treatment for COVID-19. J Transl Med 2020;18:322.

17. Yuki K, Fujiogi M, Koutsogiannaki S. COVID19 pathophysiology: A review. Clin Immunol 2020;215:108427.

18. Chen Y, Guo Y, Pan Y, Zhao ZJ. Structure analysis of the receptor binding of 2019-nCoV. Biochem Biophys Res Commun 2020;525:135-40.

19. Letko M, Marzi A, Munster V. Functional assessment of cell entry and receptor usage for SARS-CoV-2 and other lineage $\mathrm{B}$ betacoronaviruses. Nat Microbiol 2020;5:562-9.

20. Zou X, Chen K, Zou J, Han P, Hao J, Han Z. Singlecell RNA-seq data analysis on the receptor ACE2 
expression reveals the potential risk of different human organs vulnerable to $2019-\mathrm{nCoV}$ infection. Front Med 2020;14:185-92.

21. DeLuca HF. Vitamin D: Historical overview. Vitam Horm 2016;100:1-20.

22. Fraser WD, Tang JCY, Dutton JJ, Schoenmakers I. Vitamin $\mathrm{D}$ measurement, the debates continue, new analytes have emerged, developments have variable outcomes. Calcif Tissue Int 2020;106:3-13.

23. Cao H, Xu Y, de Necochea-Campion R, Baylink DJ, Payne KJ, Tang X, et al. Application of vitamin D and vitamin $\mathrm{D}$ analogs in acute myelogenous leukemia. Exp Hematol 2017;50:1-12.

24. Hou YJ, Okuda K, Edwards CE, Martinez DR, Asakura T, Dinnon KH 3rd, et al. SARS-CoV-2 reverse genetics reveals a variable infection gradient in the respiratory tract. Cell 2020;182:429-46.e14.

25. Rehan VK, Torday JS, Peleg S, Gennaro L, Vouros P, Padbury J, et al. 1Alpha,25-dihydroxy-3-epi-vitamin D3, a natural metabolite of 1alpha,25-dihydroxy vitamin D3: Production and biological activity studies in pulmonary alveolar type II cells. Mol Genet Metab 2002;76:46-56.

26. Holick MF. Vitamin D status: Measurement, interpretation, and clinical application. Ann Epidemiol 2009;19:73-8.

27. Li CH, Tang X, Wasnik S, Wang X, Zhang J, Xu Y, et al. Mechanistic study of the cause of decreased blood 1,25 -Dihydroxyvitamin D in sepsis. BMC Infect Dis 2019;19:1020.

28. Binkley N, Krueger D, Cowgill CS, Plum $\mathrm{L}$, Lake $\mathrm{E}$, Hansen $\mathrm{KE}$, et al. Assay variation confounds the diagnosis of hypovitaminosis D: A call for standardization. J Clin Endocrinol Metab 2004;89:3152-7.

29. Nguyen MH, Bryant K, O'Neill SG. Vitamin D in SLE: A role in pathogenesis and fatigue? A review of the literature. Lupus 2018;27:2003-11.

30. Bikle D. Extra renal synthesis of 1,25-dihydroxyvitamin $\mathrm{D}$ and its health implications. Clinic Rev Bone Miner Metab 2009; 7:114-25.

31. Vabret N, Britton GJ, Gruber C, Hegde S, Kim J, Kuksin M, et al. Immunology of COVID-19: Current state of the science. Immunity 2020;52:910-41.

32. Ravid A, Koren R, Maron L, Liberman UA. $1,25(\mathrm{OH}) 2 \mathrm{D} 3$ increases cytotoxicity and exocytosis in lymphokine-activated killer cells. Mol Cell Endocrinol 1993;96:133-9.

33. Hewison M. Antibacterial effects of vitamin D. Nat Rev Endocrinol 2011;7:337-45.

34. Teymoori-Rad M, Shokri F, Salimi V, Marashi SM. The interplay between vitamin $\mathrm{D}$ and viral infections. Rev Med Virol 2019;29:e2032.

35. Hansdottir S, Monick MM, Hinde SL, Lovan N, Look DC, Hunninghake GW. Respiratory epithelial cells convert inactive vitamin $\mathrm{D}$ to its active form: Potential effects on host defense. J Immunol 2008;181:7090-9.
36. Hansdottir S, Monick MM, Lovan N, Powers L, Gerke A, Hunninghake GW. Vitamin D decreases respiratory syncytial virus induction of NF-kappaBlinked chemokines and cytokines in airway epithelium while maintaining the antiviral state. $\mathrm{J}$ Immunol 2010;184:965-74.

37. Liu PT, Stenger S, Tang DH, Modlin RL. Cutting edge: Vitamin D-mediated human antimicrobial activity against Mycobacterium tuberculosis is dependent on the induction of cathelicidin. J Immunol 2007;179:2060-3.

38. Khoo AL, Chai LY, Koenen HJ, Oosting M, Steinmeyer A, Zuegel U, et al. Vitamin $\mathrm{D}(3)$ down-regulates proinflammatory cytokine response to Mycobacterium tuberculosis through pattern recognition receptors while inducing protective cathelicidin production. Cytokine 2011;55:294-300.

39. Liu PT, Stenger S, Li H, Wenzel L, Tan BH, Krutzik $\mathrm{SR}$, et al. Toll-like receptor triggering of a vitamin D-mediated human antimicrobial response. Science 2006;311:1770-3.

40. The epidemiological characteristics of an outbreak of 2019 novel coronavirus diseases (COVID-19) in China. Zhonghua Liu Xing Bing Xue Za Zhi 2020;41:145-51.

41. MacLaughlin J, Holick MF. Aging decreases the capacity of human skin to produce vitamin D3. J Clin Invest 1985;76:1536-8.

42. Gröber U, Kisters K. Influence of drugs on vitamin $\mathrm{D}$ and calcium metabolism. Dermatoendocrinol 2012;4:158-66.

43. Xu Y, Payne K, Pham LHG, Eunwoo P, Xiao J, Chi $\mathrm{D}$, et al. A novel vitamin $\mathrm{D}$ gene therapy for acute myeloid leukemia. Transl Oncol 2020;13:100869.

44. Holick MF, Binkley NC, Bischoff-Ferrari HA, Gordon CM, Hanley DA, Heaney RP, et al. Evaluation, treatment, and prevention of vitamin D deficiency: An Endocrine Society clinical practice guideline. J Clin Endocrinol Metab 2011;96:1911-30.

45. Ross AC, Manson JE, Abrams SA, Aloia JF, Brannon PM, Clinton SK, et al. The 2011 report on dietary reference intakes for calcium and vitamin D from the Institute of Medicine: What clinicians need to know. J Clin Endocrinol Metab 2011;96:53-8.

46. Petri M, Bello KJ, Fang H, Magder LS. Vitamin D in systemic lupus erythematosus: Modest association with disease activity and the urine protein-to-creatinine ratio. Arthritis Rheum 2013;65:1865-71.

47. Chen G, Wu D, Guo W, Cao Y, Huang D, Wang H, et al. Clinical and immunological features of severe and moderate coronavirus disease 2019. J Clin Invest 2020;130:2620-9.

48. Johnstone J, Parsons R, Botelho F, Millar J, McNeil $\mathrm{S}$, Fulop $\mathrm{T}$, et al. Immune biomarkers predictive of respiratory viral infection in elderly nursing home residents. PLoS One 2014;9:e108481. 
49. Fisher SA, Rahimzadeh M, Brierley C, Gration $\mathrm{B}$, Doree $\mathrm{C}$, Kimber $\mathrm{CE}$, et al. The role of vitamin $\mathrm{D}$ in increasing circulating $\mathrm{T}$ regulatory cell numbers and modulating $T$ regulatory cell phenotypes in patients with inflammatory disease or in healthy volunteers: A systematic review. PLoS One 2019;14:e0222313.

50. Lu D, Zhang J, Ma C, Yue Y, Zou Z, Yu C, et al. Link between community-acquired pneumonia and vitamin D levels in older patients. Z Gerontol Geriatr 2018;51:435-9.

51. Science M, Maguire JL, Russell ML, Smieja M, Walter $\mathrm{SD}$, Loeb M. Low serum 25-hydroxyvitamin D level and risk of upper respiratory tract infection in children and adolescents. Clin Infect Dis 2013;57:392-7.

52. Lips P, Cashman KD, Lamberg-Allardt C, BischoffFerrari HA, Obermayer-Pietsch B, Bianchi ML, et al. Current vitamin D status in European and Middle East countries and strategies to prevent vitamin D deficiency: A position statement of the European Calcified Tissue Society. Eur J Endocrinol 2019;180:P23-P54.

53. Peterson CA, Heffernan ME. Serum tumor necrosis factor-alpha concentrations are negatively correlated with serum 25(OH)D concentrations in healthy women. J Inflamm (Lond) 2008;5:10.

54. Lei GS, Zhang C, Cheng BH, Lee CH. Mechanisms of action of vitamin D as supplemental therapy for pneumocystis pneumonia. Antimicrob Agents Chemother 2017;61:e01226-17.

55. Colunga Biancatelli RML, Berrill M, Marik PE. The antiviral properties of vitamin C. Expert Rev Anti Infect Ther 2020;18:99-101.

56. Wimalawansa S. Global epidemic of coronavirusesCOVID-19: What can we do to minimize risks. EJBPS 2020;7:432-8.

57. Mohammad S, Mishra A, Ashraf MZ. Emerging role of vitamin $\mathrm{D}$ and its associated molecules in pathways related to pathogenesis of thrombosis. Biomolecules 2019;9:649.

58. Jablonski KL, Chonchol M, Pierce GL, Walker AE, Seals DR. 25-Hydroxyvitamin D deficiency is associated with inflammation-linked vascular endothelial dysfunction in middle-aged and older adults. Hypertension 2011;57:63-9.
59. Brandt JA, Churchill L, Rehman A, Ellis G, Mémet $\mathrm{S}$, Israël $\mathrm{A}$, et al. Sleep deprivation increases the activation of nuclear factor kappa B in lateral hypothalamic cells. Brain Res 2004;1004:91-7.

60. Lefebure d'Hellencourt C, Montero-Menei CN, Bernard R, Couez D. Vitamin D3 inhibits proinflammatory cytokines and nitric oxide production by the EOC13 microglial cell line. J Neurosci Res 2003;71:575-82.

61. Kowal C, Degiorgio LA, Lee JY, Edgar MA, Huerta PT, Volpe BT, et al. Human lupus autoantibodies against NMDA receptors mediate cognitive impairment. Proc Natl Acad Sci U S A 2006;103:19854-9.

62. Faust TW, Chang EH, Kowal C, Berlin R, Gazaryan IG, Bertini E, et al. Neurotoxic lupus autoantibodies alter brain function through two distinct mechanisms. Proc Natl Acad Sci U S A 2010;107:18569-74.

63. Shu Y, Su Q, Liao S, Lu T, Li R, Sun X, et al. Low serum vitamin $D$ levels and anti-N-methyl-daspartate receptor encephalitis: A case-control study. Neurochem Int 2017;102:89-94.

64. Ahn GE, Ramsey-Goldman R. Fatigue in systemic lupus erythematosus. Int $\mathrm{J}$ Clin Rheumtol 2012;7:217-27.

65. Tay SH, Ho CS, Ho RC, Mak A. 25-hydroxyvitamin D3 deficiency independently predicts cognitive impairment in patients with systemic lupus erythematosus. PLoS One 2015;10:e0144149.

66. Mok CC, Birmingham DJ, Ho LY, Hebert LA, Song $\mathrm{H}$, Rovin BH. Vitamin D deficiency as marker for disease activity and damage in systemic lupus erythematosus: A comparison with anti-dsDNA and anti-C1q. Lupus 2012;21:36-42.

67. Lima GL, Paupitz J, Aikawa NE, Takayama L, Bonfa E, Pereira RM. Vitamin D supplementation in adolescents and young adults with juvenile systemic lupus erythematosus for improvement in disease activity and fatigue scores: A randomized, doubleblind, placebo-controlled trial. Arthritis Care Res (Hoboken) 2016;68:91-8.

68. Ruiz-Irastorza G, Gordo S, Olivares N, Egurbide MV, Aguirre C. Changes in vitamin D levels in patients with systemic lupus erythematosus: Effects on fatigue, disease activity, and damage. Arthritis Care Res (Hoboken) 2010;62:1160-5. 